Track 3: The Multinational Corporation \& its Subsidiaries

Competitive Paper

An analysis of human resource management research in multinational enterprises in Australia: Highlighting the empirical deficit

\author{
Anthony McDonnell* \\ Centre for Institutional and Organisational Studies, Faculty of Business and Law, University of Newcastle \\ Callaghan, NSW 2308, Australia. \\ Tel: +61249215495 \\ anthony.mcdonnell@newcastle.edu.au
}

John Burgess

Newcastle Business School, University of Newcastle

Callaghan, New South Wales, Australia.

\begin{abstract}
Pauline Stanton
School of Management and Information Systems, Victoria University

Melbourne, Victoria, Australia.
\end{abstract}

* Corresponding author 


\section{An analysis of human resource management research in multinational enterprises in Australia: Highlighting the empirical deficit}

\section{Abstract}

There is now a vast international literature on the human resource practices of multinational enterprises (MNEs). However, empirical studies in the Australian context are limited or are just not published in the top academic journals. Consequently it is unsurprising that Australian management academics have struggled to make an impact in the field. This paper reviews publications in top tiered journals since 1990 and notes the limited number of empirical studies in respect to the human resource management, employment relations and industrial relations practices of MNEs in Australia. In particular there has been a lack of organisational level studies with the primary focus of existing research on the individual unit of analysis, primarily in the realm of expatriates or repatriates. Further, a noticeable finding is the lack of large-scale survey work meaning very little is known on even the most basic characteristics of MNEs in Australia. In noting these deficiencies we also highlight two key issues, namely a lack of comprehensive, reliable, publicly available information on who exactly are the MNEs in Australia and the bias against the discipline in respect to research funding. 


\section{Introduction}

This paper analyses top-tiered journal publications that focus on human resource management (HRM), employment relations (ER) and industrial relations (IR) in multinational enterprises (MNEs) in Australia. More specifically, we identify the number of articles published in all $B$ and higher ranked $B A R D S N E T$ classified journals in these research fields and the methodologies utilised. In so doing, we demonstrate the limited amount of research conducted on this important group or organisations. It becomes evident that there is a paucity of knowledge on the most basic characteristics of this group of organisations, which hold so much economic and social influence. The centrality and importance of MNEs to the Australian economy can not be understated, thus making the limited research surprising. By association of these findings an important question is raised, namely how can Australian academics improve the quality of research and improve penetration in the top ranking international journals.

This lack of research is unexpected considering as "political stability, a near-Asia location and a favourable business environment have made it a location of choice for many" MNEs (Johnston and Menguc, 2007: 791) and the role of MNEs in the world economy continues to increase. Harzing (2005) noted that a possible explanation behind the poor impact of Australian business and economics academics overall may be that the Australian context is not deemed interesting to international journals. However, we suggest that the nature of the Australian context should rule this out contention. Specifically, we point to the importance of the Asian economies of China, Japan and India in addition to the vital role US and UK owned organisations play in Australia. Considering the rise of the Asia-Pacific economies, Australia provides an interesting context in which to explore the activities of MNEs as it allows analysis of both the western world MNEs along with the new emerging MNEs.. 
The next section contextualises the role of MNEs in the global economy and more principally, their importance to Australia. This helps establish the importance of research in the Australian context. Following this, we detail the structured process undertaken for our review of MNE research in Australia. We then discuss the methodologies used and the broad themes covered in published work so as to provide clear evidence on the extent of knowledge in this context. Finally, we discuss some of the key challenges Australian researchers face to address the empirical deficit evident from this review paper.

\section{MNEs in a global and Australian context}

In spite of the recent global financial crisis the globalisation of production and consumption continues apace. Globalisation is bringing about a reorganisation of power on the world, national and sub-national level (cf. Phelps and Alden, 1999; Graham, 2003). Arguably the primary driver and embodiment of globalisation is the MNE. There are some 78,000 MNEs in the world today with more than 780,000 foreign subsidiaries. The employment statistics are even more remarkable with some 73 million employed by MNEs in 2006, an increase of 48 million since 1990 (UNCTAD, 2008a). Furthermore, of the world's largest 150 economic entities, 95 (63 per cent) are corporations rather than countries (Butler, 2005). Thus, it is without argument that MNEs represent a group that potentially hold enormous power even when compared against economies.

Like many other economies, the MNE plays a critical role in Australia which has a Foreign Direct Investment (FDI) to Gross Domestic Product (GDP) ratio of almost 35 per cent, considerably higher than the 27 per cent average for comparable developed countries (UNCTAD, 2008b). Australia serves as both a major importer and exporter of FDI with 2007 
inward flows of US\$22,266 million and outward flows of some US\$24,209 million (UNCTAD, 2008b). The total inward FDI stock was US\$312,275 million with an outward FDI stock of US\$277,917 million. The US is Australia's single most important source of inward FDI (accounts for almost one quarter of all inward FDI), as well as a location for Australian FDI abroad accounting for almost 43 per cent of all Australian outward investment (Foreign Investment Review Board, 2008). After the US, the UK, Japan, New Zealand and other European Union countries represent the other critical sources of FDI with varying degrees of importance with respect to inward and outward investment. China and India are critical trading partners in respect to natural resources and are now also beginning to become important countries for attracting FDI, in addition to being potentially lucrative locations for Australian organisations establishing overseas. Additionally, our analysis of the most recent World Investment Report's Top 100 non-financial sector MNEs (by foreign assets) found that 67 have operations in Australia that employ 100 or more (UNCTAD, 2008b). There are whole sectors of the Australian economy such as motor vehicles and white goods that are dominated by MNEs and many of the organisations involved in exploiting Australia's vast natural resources are actually large international enterprises.

In addition to demonstrating the influence of MNEs, we highlight the interesting context that Australia provides to study these organisations. Particularly noteworthy is the "uniquely centralised system of state regulation of industrial relations" that encompassed Australia for much of the twentieth century (McGraw and Harley, 2003: 7). The early 1990s witnessed a major change in the Australia industrial relations system whereby the government changed the centralised system to workplace and individual level bargaining. Consequently, the uniform labour arrangements that characterised Australia has gone which arguably provides 
greater scope for the introduction of innovative organisational practices further adding to the need for research on how MNEs work within this framework.

\section{MNE research in Australia: what has been done?}

We undertook a systematic analysis of all research published on MNEs in Australia in the area of HRM, ER and IR. We adopted a broad definition of what was included in our review so as to ensure an extensive picture of current research was depicted. The review focused on all $A^{*}, A$ and $B$ journals under Australian Business Deans Council Ranking System (see Table 1). This incorporated 52 journals which we deemed as potential locations for this line of research. Two journals were subsequently excluded due to access issues. The search period was confined to the period January 1990 to August 2009. However there were a small number of journals where the search conducted did not stretch as far back as 1990, either due to the journal starting post-1990 or our access did not stretch that far back. Searches were performed journal by journal using the terms 'Australia' and 'multinational' using the 'full text' function. To ensure that all articles would be included, follow up searchers were conducted where 'multinational' was replaced with 'multi-national', 'MNC' and 'MNE'. We did not use any other terms due to our desire to ensure relevant articles were not incorrectly excluded. Each article that emerged from these searches was then analysed to establish if the article involved empirical based research (i.e. first hand empirical data collection) surrounding the broad themes of HRM, ER and IR in foreign or indigenous owned MNEs. While this was a time-consuming activity, we believed it proved to be a more accurate means of capturing previous research than undertaking a keyword search on databases such as Business Source Premier, Emerald or Proquest. 
As Table 1 graphically illustrates, it is apparent that there is a lacuna of empirical research on the MNE sector in Australia. Although, there have been some excellent, informative research studies published, the overall number of published papers is markedly low. In total, we found 47 peer-reviewed journal articles published in B or higher ranked journals over the past 19 years (mean value of 2.5 articles per year). Some 19 per cent $(n=9)$ of these articles were in ' $A$ *' outlets, 49 per cent $(n=23)$ were ' $A$ ' ranked and the remaining 32 per cent $(n=15)$ were published in ' $B$ ' ranked journals $(n=15)$.

\section{Insert Table 1 here}

A more encouraging aspect of our review is that the majority of articles (89 per cent) have been published post-2000 suggesting that researchers have identified the knowledge deficit and/or need for greater quality studies. However as we note later, researchers are faced with some major challenges correcting the research deficit, not least the clear bias towards other research disciplines by the main funding body in Australia (i.e. Australian Research Council). The International Journal of Human Resource Management (8 articles) represents the most common source of articles with the Journal of Industrial Relations (7 articles) particularly popular with respect to the few published works on industrial/employment relations. Worthy of note here is that the Journal of Industrial Relations is an Australian run international journal, while the strong Asia-Pacific focus in respect to editorial board membership of the International Journal of Human Resource Management has been highlighted elsewhere (see Ozbilgin, 2004). Consequently, if these journals were excluded the situation would look conceivably worse. Surprisingly, the main national and regional management journals were not overloaded with articles on this research matter either. Indeed, we found only one 
relevant article in the Australian Journal of Management and two in the Asia Pacific Journal of Management.

From our analysis, we find that a significant number of articles are predominantly focused on the individual in terms of expatriates and repatriates (cf. Hutchings, 2003; De Cieri et al., 2009) rather than analysing practice at the organisational level. However, there are a number of papers that explore differences in HR practice and policy between foreign-owned MNEs and indigenous firms (cf. Walsh, 2001; McGraw and Harley, 2003), the transfer of HR practices in MNE subsidiaries (cf. Purcell et al., 1999; Kostova and Roth, 2002), knowledge management/transfer in MNEs (cf. Hocking et al., 2007; Yamao et al., 2009), headquarters and subsidiary relationships (cf. Chung et al., 2006; Bouquet and Birkinshaw, 2008) and labour and management relations (cf. Fairbrother and MacDonald, 2000; Bartram and Cregan, 2003). Further, it is evident that industrial relations issues are particularly underresearched, although this finding is not unique to the Australian context with Collings (2008) highlighting the limited research on industrial relations issues in MNEs. However, the 2008 Australian Research Council (ARC) Discovery Project Grant awarded to researchers at the University of Sydney (led by Professor Russell Lansbury) exploring the impact of multinational enterprises on industrial relations may help offset the lack of research in Australia.

A further point of note is that many articles are not necessarily focused on the MNE as the unit of analysis. For instance, the case study may happen to be an MNE but the nature of the organisation is not really the area of focus nor indeed is such a context taken into account. Papers were also identified which mentioned Australian MNEs but where there was no real attempt to discern the results to demonstrate what foreign MNEs in Australia or Australian- 
owned MNEs are doing. Another relatively common approach was to integrate research that covered MNEs in Australia into an Anglo-Saxon category, often for statistical reasons. These papers which do not disaggregate Australian data to any great level are excluded from the figures in Table 1 because they fail to make any major advance in knowledge about the Australian context.

Turning to the methodologies employed in these 47 peer-reviewed articles. Some 40 percent were based on one case study or a small number of case studies. Almost 45 per cent of papers based their empirical findings on surveys. The remaining 15 per cent utilised semi-structured interviews in a number of MNEs ${ }^{1}$. Further and as one would expect, a number of papers used the same case or survey for more than one of the identified papers here. For example, there were two papers based on the Australian Workplace Industrial Relations Survey (AWIRS) (McGraw and Harley, 2003; Walsh, 2001), two papers were based on CRANET (Gooderham et al., 2006; Fenton-O'Creevy et al., 2008) and two papers were based on the Best International Human Resource Management Practices Project (BIHRMP) (Huo et al., 2002; Lowe et al., 2002). The case studies and semi-structured interviews represent a growing research area in the HRM/ER disciplines and thus it is unsurprising to see high usage of these methodologies. Indeed considering the areas under investigation in many of these studies it was clear that in-depth enquiry was required due to limited knowledge in the specified subject matter. However, the lack of organisational level survey data was unexpected considering surveys represent the most common form of methodology used by researchers (cf. Church and Waclawski, 2001). We now turn to a key deficiency in survey based papers which emerged from our review.

\footnotetext{
${ }^{1}$ Again we wish to remind readers that most of these articles involved individual employees (e.g. expatriates) as the unit of analysis.
} 


\section{The representative gap in MNE research}

While we contend there are great merits in all methodological approaches as long as the methodology is suitable to address the research questions, it is apparent that existing quantitative studies on MNEs fail to provide adequately representative data. Specifically, we note the lack of attention paid to population development and sampling when undertaking these types of studies (McDonnell et al., 2007; Edwards et al., 2008).

There has been much research into analysis of response rates in individual and organisational studies (cf. Baruch and Holtom, 2008) due to its importance in determining the validity of survey results (Campion, 1993). Recently, concerns have been raised about low response rates and their negative impact on statistical power (Rogelberg et al., 2003) which will potentially produce biased results while also making it easier for studies to be discounted due to perceived credibility issues (Luong and Rogelberg, 1998). However, a much less discussed issue which has the potential to arguably cause greater damage to a study's credibility is how the population used for drawing the sample has been derived. This is somewhat surprising considering this is a critical step in determining the generalisability of research. Generally the primary objective of undertaking a quantitative study is its ability to generalise the findings from the sample to the total population. For example, the Best International Human Resource Management Practices Project suggested that it "was large in scale and scope......an intentional attribute of the research design in order to facilitate generalisability of the findings" (Geringer et al., 2002: 12). Indeed the importance of this was alluded to by Baruch and Holtom (2008) in their review of response rates. Specifically they observed that, "more important [than the response rate] is that the respondents be representative of the population being studied - that they are not systematically different in any meaningful way from the 
overall group" (Baruch and Holtom, 2008: 1153). Based on our review, we contend that this is something that researchers do not pay enough attention to.

Identifying the population is fundamental to any study because the sample drawn is generally intended to be a microcosm of the total population. Thus, if the population is not accurate and reliable the results of the study, no matter how high or low the response rate will call the results into question. This is supported by Cook et al. (2000) who, through meta-analysis of web and internet based surveys found that response representativeness was far more important than the response rate. McDonnell and colleagues (2007) have highlighted this issue of un-representative listings in the Irish context when noting that the state industrial development agencies are typically used to derive MNE population listings but that these sources exclude many key sectors meaning an unrepresentative sampling frame is then used. Additionally, Collinson and Rugman (2005) found much of the published work on MNEs is biased towards the largest, most global, well-known, primarily US-based manufacturing firms. When one considers that a prominent reason for non-response is over-surveying of some organisations (Weiner and Dalessio, 2006), deriving more accurate populations may also actually lead to improved response rates because organisations not typically contacted may be included in the selected sample. Consequently, while some organisations suffer from questionnaire overload, others are likely to be under-whelmed by research access requests.

A further issue in attempting to generalise results is the extent of non-response bias, that is, the differences between respondents and non-respondents. Attempting to analyse for nonresponse bias is an extremely difficult task because it requires having readily identifiable strata on which to compare respondents from non-respondents. Four approaches to studying non-responses have been noted; the archival approach, follow-up approach, wave approach 
and the intentions approach (see Rogelberg et al., 2003 for a discussion). We assert that one of the best means to analyse non-response bias is to accurately profile the population (Rogelberg et al., 2003). In other words, to spend time on accurately deriving the population and in so doing, a number of key strata should be identified which will allow researchers to analyse respondents against non-respondents post-fieldwork. Unfortunately analysing why specific individuals in organisations did not participate is far more difficult. However, this is arguably of less concern if the survey is about organisational practices.

Our analysis of the aforementioned articles in this paper finds that quantitative focused studies pay insufficient attention to population development. Earlier we noted that CRANET, AWIRS and the BIHRMP have been used as sources for a number of papers. However, none of these studies were exclusively focused on MNEs as the unit of analysis. These were workplace level studies that included public sector organisations. For example, CRANET was based on workplaces with 100 or greater employees (Brewster et al., 1996). Considering the scope of these studies, and specifically AWIRS, it was surprising to read the contention by Johnston and Menguc (2007: 791) in discussing the merits of their study that the "issue of representativeness was addressed via comparison with the 1995 AWIRS". Considering that AWIRS was not focused on MNEs per se and that the Johnson and Menguc (2007) study solely utilised the Dun and Bradstreet Who Owns Whom publication as the source for deriving the population, we suggest this is a somewhat inflated claim. In saying that, this study represents one of the largest studies in the Australian context with an excellent response entailing 313 subsidiaries of foreign-owned MNEs.

Researchers have tended to use an easily available source rather than spending sufficient time and effort in more accurately defining the total population (Fowler, 1988; Murphy, 1997; 
McDonnell et al., 2007). For instance, Bouquet and Birkinshaw (2008) utilised the International CEO Forum of Australia, Harzing and Noorderhaven (2006) used the Dun and Bradstreet publication Who Owns Whom and Chung et al. (2006) used the BRW Top 1000 Corporations List. Purcell and colleagues (1999) noted that there was "no comprehensive listing of Japanese MNEs in Australia" yet in spite of acknowledging this they still only utilised one database source (i.e. A Directory of Japanese Business Activity in Australia). Further, there is a failure to actually set out how researchers defined a MNE in their research. For example, Maitland et al. (2004) conducted three years of surveys of Japanese MNEs in Australia. They state that the populations were drawn from the Directories of Japanese Business Activity in Australia but there is no indication as to how they defined a Japanese MNE. Definitions of MNEs can vary from the use of employment size criteria, foreign ownership levels, foreign assets and so forth. A consequence of this is that comparing results from one study to another is problematic and possibly of questionable value.

\section{Discussion and conclusions}

This paper has reviewed publications in top international management and IR journals to establish the extent of our knowledge on the activities of MNEs in Australia. The story that emerged was one of limited published empirical research on the Australian context in quality peer-refereed outlets. Nonetheless it is important to point out that there may be other research that has been published in the Australian context found in lower ranked journals. Indeed this is likely when we take into account the work of Harzing (2005) who found that the publication patterns of Australian business and economics academics tends to be at the lower end of the spectrum in respect to quality of outlet. Specifically, she found that while quantity of articles was the highest across academic disciplines in Australia, it had the poorest record in terms of quality of publication and citations. Consequently, we suggest it is important for 
debate and discussion on how the quality of research and penetration in high quality journals can be improved by Australian academics.

We argue that there needs to be a considerable increase in research activity across the management and ER disciplines on the MNE sector in Australia. The national business system and sectoral composition (which is essentially unknown) of the MNE sector (e.g. the large number of natural resource industry MNEs) and its proximity to and extensive trading relationships with Asia makes Australia a potentially different, interesting and important context to research these organisations. Considering the power many MNEs can exert on governments and key policy makers, understanding their activities and the roles their operations play is critical to more effectively inform public policy. For instance, research in the Irish context has pointed to the strong influence of US MNEs in shaping public policy prominently achieved through government lobbying by the American Chamber of Commerce (Donaghy, 2004; Collings et al., 2008). However, we have little knowledge on the extent to which MNEs in Australia organise in the context of the institutional arrangements they face and/or the part they play in constructing the Australian social and business environment.

This research should attempt to utilise the increasing range of methodologies available to researchers including both in-depth case research and quantitative studies. In the case of quantitative studies, we argue that researchers need to spend far greater attention to how they derive study populations. By not doing so it calls the usefulness of their results into question. To date, there is a total lacuna of data on how many MNEs exist in Australia, the sectors they operate, the employment they provide, not to mind how they mange their workforces. We also suggest that published works should ensure the MNE be defined in papers so as to better 
inform future researchers in the suitability of results to compare their own empirical data with.

While we argue for greater attention be paid towards the development of survey populations, we are also cognisant of the time-and-effort issue. As highlighted elsewhere (see McDonnell et al., 2007; Edwards et al., 2008) the most commonly used databases for building study populations suffer from a number of serious deficiencies. Consequently, it has been argued that best practice is to utilise a number of sources and cross-check listings to ensure greater accuracy and reliability. We posit that the lack of reliable, publicly available directory of these businesses is likely to explain part of the low levels of research on MNEs in Australia. Undertaking the time-consuming process of cross-checking a number of listings may not always be feasible due to time and resource constraints. Indeed the resource issue is something that is likely to be correlated with the lack of high-quality published output in the business and management field. Table 2 demonstrates the outcomes of ARC Discovery Project awards for the period 2002 to $2009^{2}$. The ARC Discovery Project is the most prestigious funding source open to researchers across all disciplines in Australia. It is clearly evident that business and management academics struggle to receive funding for research projects. The highest percentage of business and management projects funded in the past eight years has been in 2009 when 1.29 per cent of the total number of funded projects were located in this discipline. This equated to just eleven research projects out 925 awards. Further, during this period there have been only two funded projects in this discipline that relate to MNEs. An important note that needs to be considered in conjunction with this analysis is that we do not know how many applications are made by business and management researchers. However, we would posit that the number of applications is likely

\footnotetext{
${ }^{2}$ Data is only available from 2002.
} 
to be far less than among the science disciplines. This assertion is based on the national research priorities set out by the Department of Innovation, Industry, Science and Research which clearly focus on science and technology. While such a focus is expected and consistent with developed economies we contend that the failure to acknowledge the importance of building human capital capacity and management skills as a key priority is short-sighted and indeed goes against the growing acknowledgment of this area by other countries. Considering the critical report by Karpin (1995) that suggested Australian managers were severely lacking in the skills required to successfully manage $21^{\text {st }}$ century organisations the failure to provide more support to this discipline may be a serious issue. In addition, considering the time and resources that are required to write an ARC Discovery Project proposal and the chances of success it is probably that researchers are turned off applying.

\section{Insert Table 2 here}

In concluding, we note that to date little research has been conducted on the activities of MNEs in Australia and that studies where conducted have suffered from a lack of comprehensiveness and representativeness. We posit that one possible explanation is the limited research funding made available to business and management researchers and suggest that this is possibly a major impediment to the development and sustainability of the Australian business. 


\section{References}

Bartram, T. and Cregan, C. 2003. Consultative employment relations in human resource management environments with a union presence. Journal of Industrial Relations, 45: 539545.

Baruch, Y. and Holtom, B. C. 2008. Survey response rate levels and trends in organizational research. Human Relations, 61: 1139-1160.

Bouquet, C. and Birkinshaw, J. 2008. Weight versus voice: how foreign subsidiaries gain attention from corporate headquarters. Academy of Management, 51: 577-601.

Brewster, C., Tregaskis, O., Hegewisch, A. \& Mayne, L. 1996. Comparative research in human research management: A review and an example. International Journal of Human Resource Management, 7: 585-604.

Butler, R. A. 2005. Corporations among largest global economic entities, rank above many countries. Available from: http:news.mongabay.com/2005/0718-worlds_largest.html. Accessed: 14 October 2008.

Campion, M. A. 1993. Article review checklist: A criterion checklist for reviewing research articles in applied psychology. Personnel Psychology, 46: 705-718.

Chung, L. H., Gibbons, P. T. and Schoch, H. P. 2006. 'The Management of Information and Managers in Subsidiaries of Multinational Corporations, British Journal of Management, 17: 153-165.

Church, A. H. and Waclawski, J. 2001. Designing and using organizational surveys: A seven step process. San Francisco: Jossey-Bass,.

Collings, D. G. 2008. Multinational corporations and industrial relations research: A road less travelled. International Journal of Management Review, 10: 173-193.

Collings, D. G., Gunnigle, P. and Morley, M. 2008. Boston or Berlin? American MNCs and the shifting contours of industrial relations in Ireland. International Journal of Human Resource Management, 19: 240-261.

Collinson, S. and Rugman, A. 2005. Studying the wrong firms: selection biases in management research, unpublished working paper, University of Warwick.

Cook, C., Heath, F. and Thompson, R. L. 2000. A meta-analysis of response rates in web-orinternet-based surveys. Educational and Psychological Measurement, 60: 821-836.

De Cieri, H., Sheehan, C., Costa, C., Fenwick, M. and Cooper, B. K. 2009. International talent flow and intention to repatriate: an identify explanation. Human Resource Development International, 12: 243-261.

Donaghy, J. 2004. Social partnership and labour market governance in the Republic of Ireland. Unpublished Ph.D thesis, School of Management and Economics, Queens University Belfast. 
Edwards, T., Tregaskis, O., Edwards, P., Ferner, A. \& Marginson, P. 2008. Charting the contours of Multinationals in Britain: Methodological challenges arising in survey-based research. Published in the Leicester Business School's Occasional Paper series and Warwick Papers in Industrial Relations.

Fairbrother, P. and MacDonald, D. 2000. Multinational versus state ownership: labourmanagement relations in the electricity industry. Journal of Industrial Relations, 42: 314-333.

Fenton-O'Creevy, M., Gooderham, P. and Nordhaug, O. 2008. Human resource management in US subsidiaries in Europe and Australia: centralisation or autonomy?. Journal of International Business Studies, 39: 151-166.

Foreign Investment Review Board. 2008. Annual Report 2007-08. Barton, ACT:

Commonwealth of Australia.

Fowler, F. J. 1988. Survey Research Method., London: Sage.

Geringer, J. M., Frayne, C. A. and Milliman, J. F. 2002. In search of "best practices" in international human resource management: research design and methodology. Human Resource Management, 41: 5-30.

Gooderham, P., Nordhaug, O. and Ringdal, K. 2006. National embeddedness and calculative human resource management in US subsidiaries in Europe and Australia. Human Relations, 59: 1491-1513.

Graham, E. M. 2003. Attractive Foreign Direct Investment to the United States: The Joust between the Federal Government and the States. In N. A. Phelps and P. Rains (Eds.). The New Competition for Inward Investment. Cheltenham: Edward Elgar.

Harzing, A. W. 2005. Australian Research Output in Economics \& Business: High Volume, Low Impact. Australian Journal of Management, 32: 183-200.

Harzing, A. W. and Noorderhaven, N. 2006. Geographic distance and the role and management of subsidiaries: The case of subsidiaries down-under. Asia Pacific Journal of Management, 23: 167-185.

Hocking, J. B., Brown, M. and Harzing, A. W. 2007. Balancing global and local strategic contexts: expatriate knowledge transfer, applications and learning within a transnational organisation. Human Resource Management, 46: 513-533.

Huo, Y. P., Huang, J. H. and Napier, N. K. 2002. Divergence or Convergence: A CrossNational Comparison of Personnel Selection Practices. Human Resource Management, 41: $31-44$.

Hutchings, K. 2003. .Cross-cultural preparation of Australian expatriates in organisations in China: the need for greater attention to training. Asia Pacific Journal of Management, 20: 375-396. 
Johnston, S. and Menguc, B. 2007. Subsidiary size and the level of subsidiary autonomy in multinational corporations: a quadratic model investigation of Australian subsidiaries. Journal of International Business Studies, 38: 787-801.

Karpin, D. S. 1995. Enterprising nation: Renewing Australia's managers to meet the challenges of the Asia-Pacific century. Executive summary report of the Industry Task Force on Leadership and Management Skills, Canberra: Australian Government Publication Service.

Kostova, T. and Roth, K. 2002. Adoption of organizational practice by subsidiaries of multinational corporations: institutional and relational effects. Academy of Management Journal, 45: 215-233.

Lowe, K. B., Milliman, J., De Cieri, H. and Dowling, P. J. 2002. International Compensation Practices: A Ten Country Comparative Analysis. Human Resource Management, 41: 45-66.

Luong, A. and Rogelberg, S. G. 1998. How to increase your survey response rate. The Industrial-Organizational Psychologist, 36: 61-65.

Maitland, E., Nicholas, S., Purcell, W. and Smith, T. 2004. Regional Learning Networks: Evidence from Japanese MNEs in Thailand and Australia. Management International Review, 44: 87-104.

McDonnell, A., Lavelle, J., Gunnigle, P. and Collings, D.G. 2007. Management research on multinational corporations: A methodological critique. Economic and Social Review, 38: 235258.

McGraw, P. and Harley, B. 2003. Industrial Relations and Human Resource Management Practices in Australian and Overseas-Owned Workplaces: Global or Local?. Journal of Industrial Relations, 45: 1-22.

Murphy, M. 1997. Conducting Survey Research: A Practical Guide. In T. Brannick and W. Roche (Eds.), Business Research Methods. Dublin: Oak Tree Press.

Ozbilgin, M. 2004. "International" human resource management: Academic parochialism in editorial boards of the "top" 22 journals on international human resource management. Personnel Review, 33: 205-221.

Phelps, N. A. and Alden, J. 1999. Foreign Direct Investment and the Global Economy. London: The Stationery Office.

Purcell, W., Nicholas, S., Merrett, D. and Whitwell, G. 1999. The transfer of human resource and management practices by Japanese multinationals to Australia: do industry, size and experience matter?. International Journal of Human Resource Management, 10: 72-88.

Rogelberg, S. G., Conway, J. M., Sederburg, M. E., Spitzmuller, C., Aziz, S. and Knight, W. E. 2003. Profiling Active and Passive Nonrespondents to an Organizational Survey. Journal of Applied Psychology, 88: 1104-1114. 
UNCTAD 2008a. Development and Globalization: Facts and Figures. New York and Geneva: UNCTAD.

UNCTAD 2008b. World Investment Report 2008. Transnational Corporations and the Infrastructure Challenge. New York and Geneva: UNCTAD.

Walsh, J. 2001. Human resource management in foreign-owned workplaces: evidence from Australia. International Journal of Human Resource Management, 12: 425-444.

Weiner, S. P. and Dalessio, A. T. 2006. Oversurveying: Causes, consequences, and cures. In A. I. Kraut (Ed.). Getting action from organizational surveys: New concepts, methods and applications. San Francisco, CA: Jossey-Bass.

Yamao, S., De Cieri, H. and Hutchings, K. 2009. Transferring subsidiary knowledge to global headquarters: subsidiary senior executives' perceptions of the role of HR configurations in the development of knowledge stocks. Human Resource Management, 48: 531-554. 
Table 1: A review of MNE research in Australia

\begin{tabular}{|c|c|c|c|}
\hline $\begin{array}{c}\text { Journal Name (Deans Council } \\
\text { Ranking) }\end{array}$ & $\begin{array}{c}\text { Number } \\
\text { of articles }\end{array}$ & $\begin{array}{c}\text { Journal Name (Deans Council } \\
\text { Ranking) }\end{array}$ & $\begin{array}{c}\text { Number } \\
\text { of articles }\end{array}$ \\
\hline Academy of Management & 2 & Management Learning & 0 \\
\hline Administrative Science Quarterly & 0 & $\begin{array}{l}\text { New Technology, Work and } \\
\text { Employment }\end{array}$ & 0 \\
\hline British Journal of Industrial Relations & 0 & Organization & 0 \\
\hline Human Resource Management & 4 & Organizational Dynamics & 0 \\
\hline $\begin{array}{l}\text { Industrial Relations: A Journal of } \\
\text { Economy and Society }\end{array}$ & No access & Work, Employment and Society & 0 \\
\hline $\begin{array}{l}\text { Journal of International Business } \\
\text { Studies }\end{array}$ & 2 & Asia-Pacific Journal of Management & 2 \\
\hline Journal of Management & 0 & Australian Journal of Management & 1 \\
\hline Journal of Management Studies & 0 & Business Strategy and the Environment & 0 \\
\hline Journal of Organizational Behavior & 0 & $\begin{array}{l}\text { Employee Relations: The International } \\
\text { Journal }\end{array}$ & 3 \\
\hline Management Science & 0 & $\begin{array}{l}\text { Human Resource Development } \\
\text { International }\end{array}$ & 1 \\
\hline Organization Science & 0 & $\begin{array}{l}\text { Human Resource Development } \\
\text { Quarterly }\end{array}$ & 0 \\
\hline Organization Studies & 1 & Industrial Relations Journal & 0 \\
\hline $\begin{array}{l}\text { Organizational Behavior and Human } \\
\text { Decision Processes }\end{array}$ & 0 & $\begin{array}{l}\text { International Journal of Cross-Cultural } \\
\text { Management }\end{array}$ & 0 \\
\hline Strategic Management Journal & 0 & International Journal of Manpower & 4 \\
\hline The Journal of Business & 0 & $\begin{array}{l}\text { International Studies of Management } \\
\text { and Organization }\end{array}$ & 1 \\
\hline Academy of Management Perspectives & 0 & Journal of General Management & 0 \\
\hline British Journal of Management & 1 & Journal of International Management & 0 \\
\hline $\begin{array}{l}\text { European Journal of Industrial } \\
\text { Relations }\end{array}$ & 0 & Journal of Management Inquiry & 0 \\
\hline Gender, Work and Organization & 0 & Journal of Labour Research & No access \\
\hline Group \& Organization Management & 0 & $\begin{array}{l}\text { Journal of Management and } \\
\text { Organization }\end{array}$ & 1 \\
\hline Human Relations & 2 & Labour and Industry & 0 \\
\hline Human Resource Management Journal & 1 & $\begin{array}{l}\text { Leadership and Organization } \\
\text { Development Journal }\end{array}$ & 0 \\
\hline $\begin{array}{l}\text { International Journal of Human } \\
\text { Resource Management }\end{array}$ & 8 & Organization Development Journal & 0 \\
\hline Journal of Industrial Relations & 7 & Personnel Review & 1 \\
\hline Journal of World Business & 0 & $\begin{array}{l}\text { Thunderbird International Business } \\
\text { Review }\end{array}$ & 1 \\
\hline Management International Review & 4 & Total Published Articles & 47 \\
\hline
\end{tabular}


Table 2: A review of Australian Research Council (ARC) Discover Grant Outcomes 2002-2009

\begin{tabular}{|c|c|c|c|c|c|}
\hline Year & $\begin{array}{c}\text { Grants Awarded to } \\
\text { Business \& Management }\end{array}$ & $\begin{array}{c}\text { Total Grants } \\
\text { Awarded }\end{array}$ & $\begin{array}{c}\text { \% of Business \& } \\
\text { Management Grants } \\
\text { out of Total Awards }\end{array}$ & $\begin{array}{c}\text { Grants related to } \\
\text { Business \& } \\
\text { Management in MNEs } \\
\end{array}$ & $\begin{array}{c}\text { Title \& Researcher Names of } \\
\text { Business \& Management in MNE } \\
\text { Grants } \\
\end{array}$ \\
\hline 2009 & 11 & 925 & $1.29 \%$ & 0 & N/A \\
\hline 2006 & 8 & 822 & $0.97 \%$ & 0 & $\mathrm{~N} / \mathrm{A}$ \\
\hline 2005 & 8 & 917 & $0.87 \%$ & 0 & $\mathrm{~N} / \mathrm{A}$ \\
\hline 2004 & 8 & 1055 & $0.76 \%$ & 1 & $\begin{array}{c}\text { 'Babel in business: How language } \\
\text { differences influence management } \\
\text { in multinationals? - } \\
\text { Prof. A.-W. Harzing }\end{array}$ \\
\hline
\end{tabular}

